\title{
Saline Water Impact on Water Use Efficiency of Bitter Melon (Momordica charantia L) Using Drip Irrigation
}

\author{
Kamran Baksh Soomro ${ }^{1 D},{ }^{1}$ M. M. Shaikh, ${ }^{2}$ Sanyogita Andriyas, ${ }^{3}$ \\ and Muhammad Rizwan Shahid $\mathbb{D}^{4}$ \\ ${ }^{1}$ Institute of Plant Introduction, Southern Zone Agricultural Research Center, Pakistan Agricultural Research Council, \\ Karachi University Campus, Karachi, Pakistan \\ ${ }^{2}$ Department of Basic Sciences and Related Studies, Mehran University of Engineering and Technology, Jamshoro, Pakistan \\ ${ }^{3}$ School of Engineering and Technology, Asian Institute of Technology, Pathumthani, Thailand \\ ${ }^{4}$ Institute of Soil and Environmental Sciences, University of Agriculture Faisalabad, Faisalabad, Pakistan \\ Correspondence should be addressed to Kamran Baksh Soomro; kamisoomro75@hotmail.com
}

Received 9 October 2021; Revised 20 December 2021; Accepted 23 December 2021; Published 12 January 2022

Academic Editor: İbrahim Kahramanoğlu

Copyright ( 2022 Kamran Baksh Soomro et al. This is an open access article distributed under the Creative Commons Attribution License, which permits unrestricted use, distribution, and reproduction in any medium, provided the original work is properly cited.

\begin{abstract}
Water shortage is a real problem in many parts of the world and finding alternative solutions such as the application of saline water in cropping systems is highly appreciated. Research on drip irrigation and soil salinity is still inadequate, and their effect on crop yield and water use efficiency (WUE) is a huge challenge for small farmers. The present study was conducted in Malir, a semiarid region in the Sindh province of Pakistan. The purpose was to estimate the effects of two different qualities of irrigation water including fresh quality water $\left(\mathrm{IT}_{1} 0.56 \mathrm{dS} \mathrm{m}^{-1}\right)$ and saline groundwater $\left(\mathrm{IT}_{2} 2.89 \mathrm{dS} \mathrm{m}^{-1}\right)$ on WUE using drip irrigation technology in 2018-19. The experimental design was complete randomized block design (RCBD) with two treatments of irrigation: (1) freshwater $\left(\mathrm{IT}_{1}\right)$ with $0.56 \mathrm{dS} \mathrm{m}^{-1}$ electrical conductivity and (2) saline water $\left(\mathrm{IT}_{2}\right)$ with $2.89 \mathrm{dS} \mathrm{m}^{-1}$ electrical conductivity. The average biomass and crop yield under $\mathrm{IT}_{1}$ were $10.2 \mathrm{t}^{\mathrm{ha}} \mathrm{a}^{-1}$ and $7.4 \mathrm{t} . \mathrm{ha}^{-1}$, respectively, and were found higher than those under IT 2 $\left(7.3 \mathrm{t}^{-1}\right.$ and $4.2 \mathrm{t}^{-h a^{-1}}$, respectively). Hence, both the treatments remained equally effective in season 1 as compared to season 2 $(p \leq 0.05)$. The WUE of bitter melon under $\mathrm{IT}_{1}$ was 1.60 and $1.56 \mathrm{~kg} \cdot \mathrm{m}^{-3}$ in seasons 1 and 2 , respectively, and was higher than those under $\mathrm{IT}_{2}$ which were observed 1.21 and $1.07 \mathrm{~kg} \cdot \mathrm{m}^{-3}$ in seasons 1 and 2 , respectively.
\end{abstract}

\section{Introduction}

The unavailability of freshwater is a serious worldwide threat, especially in dry climatic conditions [1] as the global population is facing an extreme shortage of freshwater [2]. Close to $92 \%$ freshwater of the world is linked to agriculture [3]; thus, there is a growing concern about declining freshwater supplies, which may endanger meeting the growing demand of several goods and services [4]. The water shortage limits sustainable agricultural development around the world [5]. The groundwater abstraction rate is growing by $2 \%$ per year globally [6]. In the year 2000 , approximately $75 \%$ of all water withdrawals accounted for agricultural purposes in developing countries with a probable increase requirement of $14 \%$ by 2030 in order to meet food demands [7]. Therefore, the world is expected to face a $40 \%$ water deficit globally under the present situation [8]. Irrigation water comprising large amounts of sodium is of special concern due to sodium's effects on the soil and posing sodium hazard [9]. Salt intrusion is the most significant hazard causing crop reduction and unsuitable environmental and hydrological conditions that limit the normal crop development [10]. Nevertheless, the effects of each component of salinity such as anions and cations are quite different on plant growth and production, ranging from beneficial to very toxic $[11,12]$. Salinity problems occurred in arid and semiarid regions due to the hot and dry weather, thus 
leading to a high evapotranspiration rate and may cause the salt concentration to increase in the soil [13].

For several years, the drip irrigation system has witnessed global promotion [14]. Besides, farmers have adapted this system according to their specific conditions, and its performance has remained dynamic [15]. A drip irrigation system attached with fertigation could increase yield up to $60 \%$ over surface irrigation [16]. For enhancing water use efficiency (WUE), this system was used in studies in South Asia [17]. In many parts of the Middle East including Iran, drip irrigation is the major method of irrigation of cropping lands due to limited water availability $[18,19]$.

Bitter gourd (Momordica charantia L), also identified as bitter melon, is cultivated in the Northern Territory, Queensland and New South Wales, and a slight quantity in Western Australia [20]. This crop is grown in Pakistan with a yearly production of $57190 \mathrm{t}$ [21].

\section{Material and Methods}

2.1. Experimental Site. The experimental site was situated in Malir, Karachi-the southern Sindh, Pakistan (Figure 1). The texture of the experimental soil was sandy loam, whereas the climate of this area is warm and humid; the maximum temperature in summer surpasses $40^{\circ} \mathrm{C}$. The evaporation rate in the southern zone of Sindh is comparatively higher than that in elsewhere in Pakistan [22]. The average yearly precipitation has been $217 \mathrm{~mm}$, while due to the vicinity to the sea, the relative humidity ranges between $52 \%$ and $78 \%$ [23].

2.2. Experimental Design. The experimental flow chart is shown in Figure 2. An experimental block of $20.25 \mathrm{~m} \times 24 \mathrm{~m}$ was selected, tilled thoroughly, and levelled partially. This block was further separated into two equal sub-blocks by complete randomized block design (RCBD), replicated thrice with a separate block of $20.25 \mathrm{~m}$ in $12 \mathrm{~m}\left(243 \mathrm{~m}^{2}\right)$ (Figure 3). Two irrigation treatments, one in each block, applied were $\mathrm{IT}_{1}\left(\mathrm{EC} 0.56 \mathrm{dS} \mathrm{m}^{-1}\right)$ and $\mathrm{IT}_{2}\left(\mathrm{EC} 2.89 \mathrm{dS} \mathrm{m}^{-1}\right)$.

2.3. Soil and Water Analysis. To determine the soil physical and chemical properties including soil salinity, texture, field capacity (FC), dry bulk density (DBD), and wilting point (WP), 18 soil samples ( 9 from each block) were drawn from the experimental block at the soil depth of $0-15,15-30$, and $30-60 \mathrm{~cm}$ before sowing the crop. Moisture content (MC) of the soil was determined using the equation given in [24]. For chemical analysis including EC, $\mathrm{pH}, \mathrm{SAR}$, and ESP, these soil samples were mixed to obtain a composite sample in plastic bags. The composite soil samples were analyzed. The electrical conductivity (EC) was determined by using a digital EC meter (model HI-8333), while the $\mathrm{pH}$ was determined by using a digital pH meter (model SP-34 sunteor [25].

\subsection{Installation of Drip Irrigation System and Its Performance.} A drip system of irrigation was installed at the experimental site with a distance of $70 \mathrm{~cm}$ between the two laterals. A total of 65 drippers were fixed on a single lateral with a space of $30 \mathrm{~cm}$ between each plant. To observe the discharge rate of the drippers, out of 10 laterals, six lateral lines with three in each treatment, lateral 1,3 , and 5 under $\mathrm{IT}_{1}\left(\mathrm{EC}_{\mathrm{iw}} 0.56 \mathrm{dS} . \mathrm{m}^{-1}\right)$ and lateral 6, 8, and 10 under $\mathrm{IT}_{2}\left(\mathrm{EC}_{\mathrm{iw}} 2.89 \mathrm{dS} . \mathrm{m}^{-1}\right)$, were selected. There were five laterals in each sub-block, with 65 drippers on each lateral. For this purpose, 65 plastic bowls with I L volume were used, and the discharge rate of each dripper, in terms of lit.hr ${ }^{-1}$, was calculated.

2.4.1. Computation of Uniformity Coefficient. The uniformity coefficient of the drip system of irrigation was calculated on the release rate of the drippers. The uniformity coefficient of the selected laterals 1,3 , and 5 as well as 6,8 , and 10 under $\mathrm{IT}_{1}$ and $\mathrm{IT}_{2}$, respectively, were determined according to prior research [26].

2.5. Crop Sowing and Fertilizer Application. Under the drip system of irrigation, the crop was cultivated in two consecutive seasons of May 2017 and Nov 2017. With drip irrigation, under feasible soil conditions, di-ammonium phosphate (DAP) and nitrogen fertilizer (227 gm and 115 gm per acre, respectively) were applied in the soil in each sub-block [27].

2.6. Irrigation Application and Soil Moisture Measurement. A tensiometer including a vacuum gauge was inserted at $0.2 \mathrm{~m}$ depth under the drippers of each site to observe soil moisture for irrigation scheduling. The tensiometers were examined two times daily (i.e., at 08:00 and 17:00), and the time of irrigation was recorded through a water meter connected to the drip irrigation system.

2.7. Agronomic Observations. Agronomic data recorded comprised fruit weight (gm) and length and diameter in $\mathrm{cm}$. For calculating biomass in 10-30 days interval, six M. charantia plants from each block were selected randomly and oven-dried for 24 hours at $70^{\circ} \mathrm{C}$ to constant weights [28].

Overall, 12 plants, six from each treatment, were selected and harvested for agronomic observations. The harvested fruit was weighed by using a digital balance. The fruit length and diameter were measured by a tape and a Vernier calliper, respectively. The agronomic observations for season 1 were recorded fortnightly from the end of July 2018 to September 2019. Nevertheless, for season 2, the same observations were recorded from December 2019 to March 2020.

2.8. Crop Yield and Water Use Efficiency. The mature bitter gourd fruits were harvested from both experimental subblocks frequently, and the yields were recorded. Eventually, the water use efficiency (WUE) was calculated by using the formula described in [29].

$$
\mathrm{WUE}=\frac{Y}{W}
$$

where WUE is the water use efficiency in $\mathrm{kg} \cdot \mathrm{m}^{-3}, Y$ is the crop yield in $\mathrm{kg} \cdot \mathrm{ha}^{-1}$, and $W$ is the total water used $\mathrm{n}$ $\mathrm{m}^{3} \cdot \mathrm{ha}^{-1}$. 


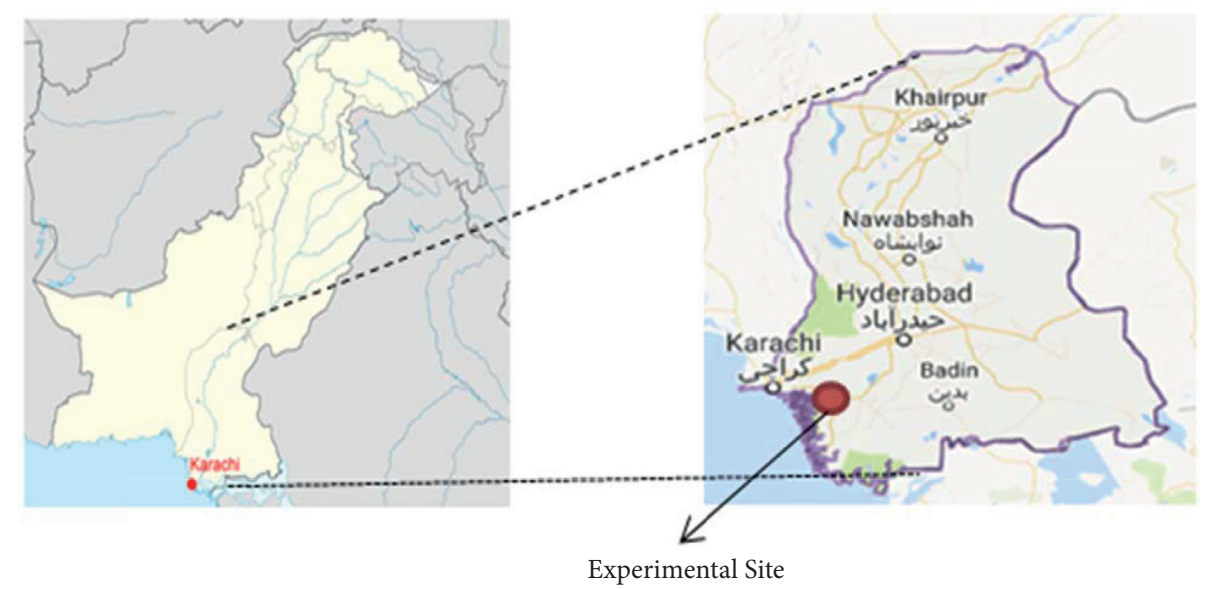

FIGURE 1: Location map of the experimental site.

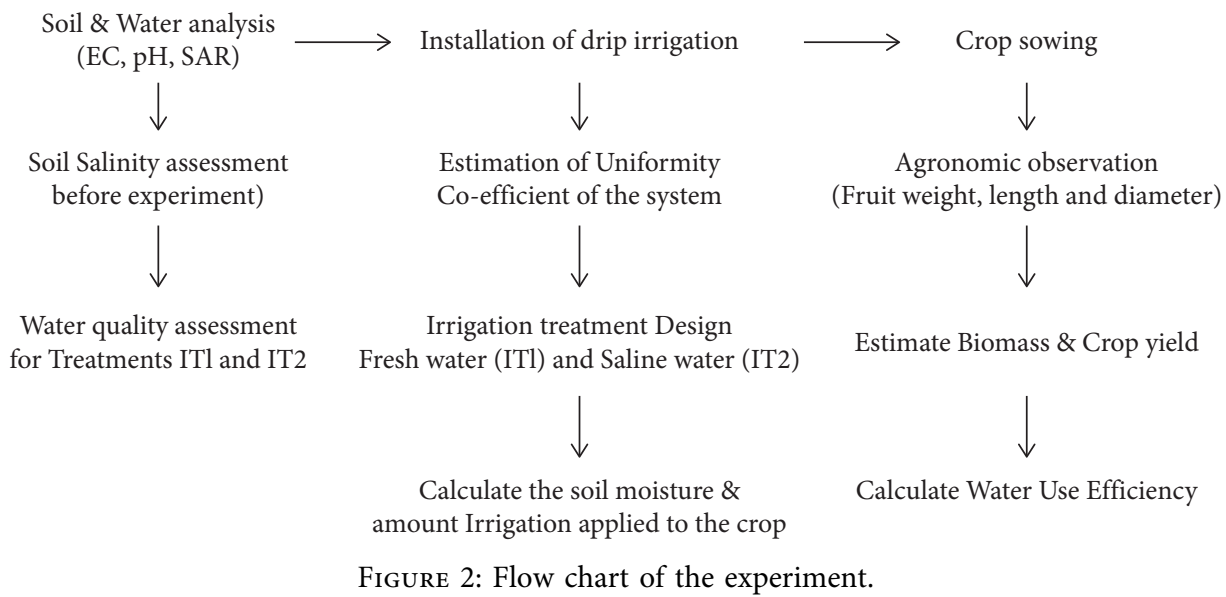

2.9. Statistical Analysis. Using SPSS version 25.0, a two-way analysis of variance (ANOVA) was run to analyze the significance of the agronomic data including fruit length (L), weight $(\mathrm{W})$, and diameter $(\mathrm{D})$, recorded using $\mathrm{IT}_{1}$ and $\mathrm{IT}_{2}$ in season 1 and 2 .

\section{Results and Discussion}

3.1. Irrigation Application and Uniformity Coefficient. The experimental soil was sandy loam in nature; hence, light irrigation, at a steady interval of two days, was applied to retain the soil moisture and avoid plant stress. A total of 53 applications of irrigation were given to bitter gourd from planting till the end of the crop. Overall, $81.8 \mathrm{~m}^{3}$ of water was applied under each treatment, in season 1, in summer (May 2017-September 2017). Besides, 48 irrigations, in season 2, in winter (Nov 2017-Mar 2018), were applied where $47.04 \mathrm{~m}^{3}$ of water was used for each treatment as the requirement of water is less in winters. In the drip irrigation system, the uniformity coefficient of drippers in selected laterals, i.e., 1, 3, and 5 in block 1 , whereas 6, 8, and 10 in block 2 were figured as 93, 94, 94, 96,94 , and $96 \%$, respectively. The average uniformity coefficient was $94 \%$.

3.2. Agronomic Observations. The analysis of fruit length, weight, and diameter under $\mathrm{IT}_{1}$ and $\mathrm{IT}_{2}$ for seasons 1 and 2 are given in Tables 1 and 2. It was found that fruit length, weight, and diameter under $\mathrm{IT}_{1}$ and $\mathrm{IT}_{2}$ were higher in season 1 than in season 2. This agronomic behaviour of the plant in season 1 is due to warm weather as bitter melon is a summer crop and produces better results in a warm climate. A similar field experiment, in Caspian seawater in Iran [30], showed that the yield decreased $10-14 \%$ for every $1 \mathrm{dS} \mathrm{m} \mathrm{m}^{-1}$ increase in soil salinity and showed that the salinity threshold value for oleic sunflower is about $1.6 \mathrm{dS} \mathrm{m}^{-1}$ in the Sari region.

The statistical analysis of biomass and crop yield under $\mathrm{IT}_{1}$ and $\mathrm{IT}_{2}$ for seasons 1 and 2 are shown in Tables 3 and 4 . It was observed that the freshwater having EC less than $4.0 \mathrm{dS} \mathrm{m}^{-1}$ had the highest yield of $1.52 \mathrm{~kg}$ while the lowest yield was found $0.66 \mathrm{~kg}$ using water with $\mathrm{EC} 10 \mathrm{dS} \mathrm{m}^{-1}$ as the 


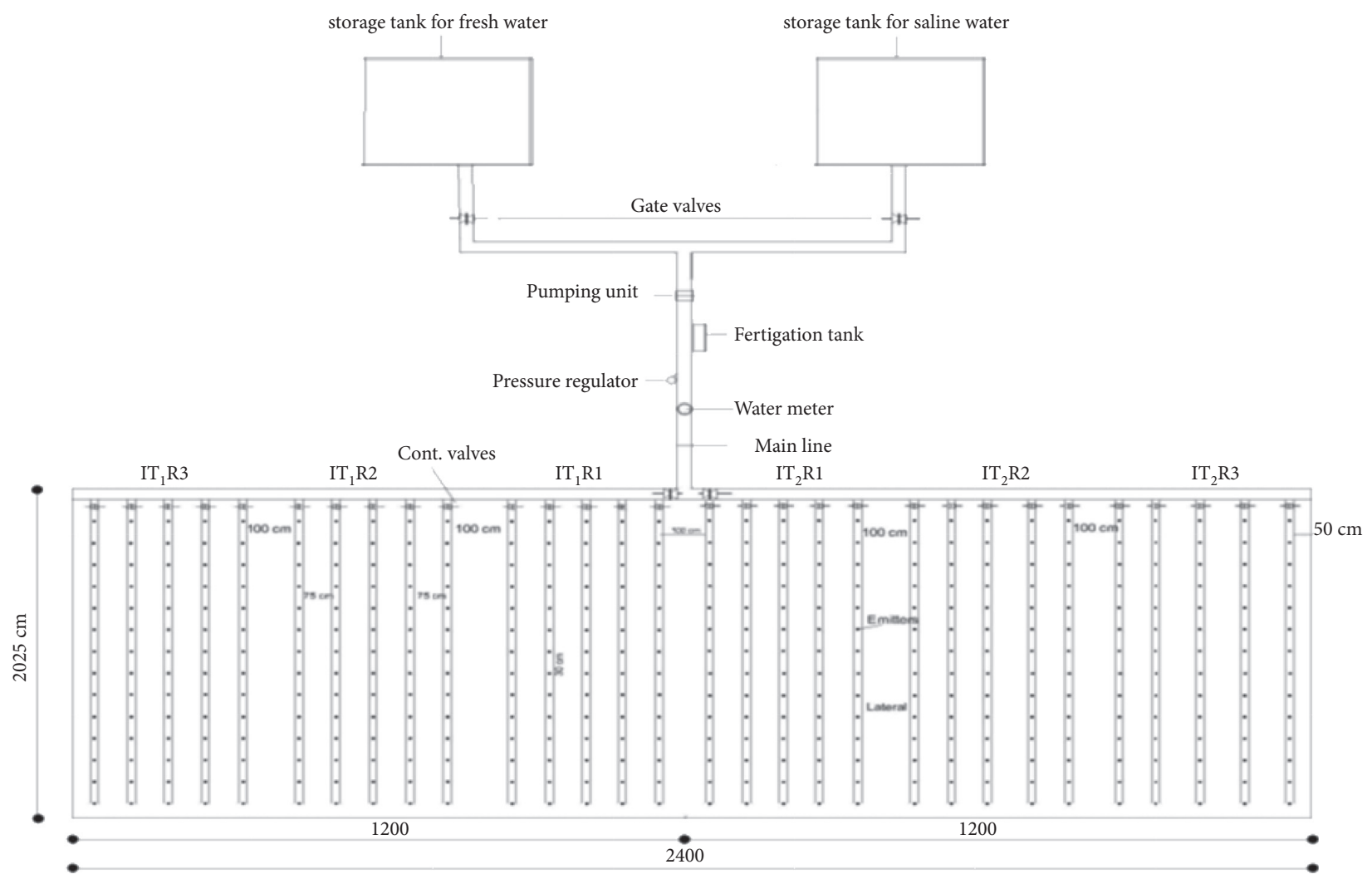

Figure 3: Design of drip irrigation in an experiment field.

TABle 1: Descriptive statistics for fruit length (L), weight (W), and diameter (D) under $\mathrm{IT}_{1}$ and $\mathrm{IT}_{2}$ for season 1.

\begin{tabular}{lcccc}
\hline Variables & Mean & $N$ & Standard deviation & Standard error \\
\hline L_S1_T & 12.61 & 36 & 1.71 & 0.28 \\
L_S1_T & 11.22 & 36 & 1.06 & 0.17 \\
W_S1_T & 53.01 & 36 & 5.91 & 0.98 \\
W_S1_T & 45.98 & 36 & 4.91 & 0.81 \\
D_S1_T & 03.21 & 36 & 0.56 & 0.09 \\
D_S1_T & 02.44 & 36 & 0.40 & 0.06 \\
\hline
\end{tabular}

biomass and crop yield were higher in season 1 under $\mathrm{IT}_{1}$ than in season 2. The results are in line with those of the study by Ahmed et al. [31] who conducted a field experiment on tomatoes using saline irrigation water in Bangladesh. The authors concluded that the tomatoes irrigated with freshwater with EC $<4.0 \mathrm{dS} \mathrm{m}^{-1}$ had the highest fruit yield of $1.52 \mathrm{~kg}$ while the lowest yield of $0.667 \mathrm{~kg}$ was found under higher salinity with EC $10 \mathrm{dS} \mathrm{m}^{-1}$. These outcomes also in connection with the results of the study conducted by the authors in $[32,33]$ concluded that the yield of crop species grown in semiarid region could be improved if the salinity of irrigation water is decreased.

3.3. Crop Yield and Water Use Efficiency. The crop was harvested from both experimental sub-blocks, and the yield was weighed and recorded on different dates. It was further calculated as total yield per ton. For season 1, the WUE
TABLE 2: Descriptive statistics for fruit length (L), weight (W) and diameter (D) under $\mathrm{IT}_{1}$ and $\mathrm{IT}_{2}$ for season 2 .

\begin{tabular}{lcccc}
\hline Variables & Mean & $N$ & Standard deviation & Standard error \\
\hline L_S2_T $_{1}$ & 08.43 & 36 & 1.47 & 0.24 \\
L_S2_T $_{2}$ & 07.00 & 36 & 1.08 & 0.18 \\
W_S2_T & 44.56 & 36 & 5.73 & 0.95 \\
W_S2_T & 38.51 & 36 & 5.10 & 0.85 \\
D_S2_T $_{1}$ & 02.71 & 36 & 0.48 & 0.08 \\
D_S2_T & 01.98 & 36 & 0.36 & 0.06 \\
\hline
\end{tabular}

under $\mathrm{IT}_{1}$ and $\mathrm{IT}_{2}$ was 1.60 and $1.21 \mathrm{~kg} \cdot \mathrm{m}^{-3}$, respectively. However, the WUE slightly decreased in the second season, recording 1.56 and $1.07 \mathrm{~kg} \cdot \mathrm{m}^{-3}$ under $\mathrm{IT}_{1}$ and $\mathrm{IT}_{2}$, respectively, as shown in Table 5 .

The water quality values showed that the groundwater $\left(\mathrm{IT}_{2}\right)$ was saline $\left(\mathrm{EC}_{\mathrm{iw}} 1.5\right.$ to $3.0 \mathrm{dS} \cdot \mathrm{m}^{-1}, \mathrm{pH}<8.0$, and $\mathrm{SAR}<10.0)$. The uniformity of the drip irrigation system was satisfactory and in line with the past study [34] which reported the highest uniformity coefficient $(99.2 \%)$. The distribution uniformity (97.4\%) was found under the drip irrigation at a pressure of $1.5 \mathrm{~kg} \mathrm{~cm}^{-2}$ using a $25 \mathrm{~m}$ long lateral line in New Delhi, India. Moreover, this system was reported to reduce water usage by minimizing up to $75 \%$ runoff.

The fruit length, fruit weight, and fruit diameter were found to be higher in season 1 under $\mathrm{IT}_{1}$ than those in season 2 under $\mathrm{IT}_{2}$. These results supported the hypothesis that $\mathrm{IT}_{1}$ is beneficial for plant characteristics (i.e., length, weight, and 
TABle 3: Descriptive statistics with confidence bounds for the biomass (bio) data for seasons 1 and 2 with IT $_{1}$ and IT $_{2}$.

\begin{tabular}{lccccr}
\hline Variables & $N$ & Mean & Standard error & Standard deviation & \multicolumn{2}{c}{$\begin{array}{c}\text { con\%idence bounds } \\
\text { Lower }\end{array}$} \\
\hline Bio_S1_T & 22 & 6.91 & 0.71 & 3.35 & 5.40 \\
Bio_S1_T & 22 & 5.43 & 0.32 & 1.51 & 4.74 \\
Bio_S2_T & 18 & 4.77 & 0.49 & 2.12 & 6.42 \\
Bio_S2_T & 18 & 3.20 & 0.30 & 1.28 & 6.71 \\
\hline
\end{tabular}

TABle 4: Descriptive statistics with confidence bounds for the crop yield (cy) data for seasons 1 and 2 with $\mathrm{IT}_{1}$ and $\mathrm{IT}_{2}$.

\begin{tabular}{lccccc}
\hline Variables & $N$ & Mean & Standard error & Standard deviation & \multicolumn{2}{c}{$\begin{array}{c}\text { confidence bounds } \\
\text { Lower }\end{array}$} \\
\hline Cy_S1_T 1 Upper & & & & 3.01 & 4.50 \\
Cy_S1_T & 22 & 6.61 & 0.64 & 1.46 & 2.96 \\
Cy_S2_T & 22 & 5.03 & 0.31 & 1.95 & 5.69 \\
Cy_S2_T & 18 & 4.14 & 0.46 & 1.46 & 5.10 \\
\hline
\end{tabular}

TABLE 5: Crop yield and water use efficiency.

\begin{tabular}{lcccc}
\hline Irrigation treatment & Crop yield $\left(\mathrm{t} . \mathrm{ha}^{-1}\right)$ season 1 & Crop yield $\left(\mathrm{t} \mathrm{ha}^{-1}\right)$ season 2 & WUE $\left(\mathrm{kg} \mathrm{m}^{-3}\right)$ season 1 & WUE $\left(\mathrm{kg} \mathrm{m}^{-3}\right)$ season 2 \\
\hline $\mathrm{IT}_{1}\left(\mathrm{EC} 0.56 \mathrm{dS} \cdot \mathrm{m}^{-1}\right)$ & 45.5 & 22.6 & 1.60 & 1.56 \\
$\mathrm{IT}_{2}\left(\mathrm{EC} 2.89 \mathrm{dS} \cdot \mathrm{m}^{-1}\right)$ & 33.4 & 14.5 & 1.21 & 1.07 \\
\hline
\end{tabular}

diameter). Therefore, it can be concluded that $\mathrm{IT}_{1}$ elicits a significant improvement in the length, weight, and diameter of bitter gourd fruit. The crop yield achieved under $\mathrm{IT}_{1}$ was comparatively higher than that under $\mathrm{IT}_{2}$ because, under $\mathrm{IT}_{1}$ treatment, freshwater did not influence the crop yield. However, under $\mathrm{IT}_{2}$, the yield somewhat decreased in comparison with $\mathrm{IT}_{1}$. This reduction was attributable to the higher vegetative growth in the summer season when it was able to support a higher fruit plant. Overall, it was observed that the biomass and crop yield were higher in season 1 under $\mathrm{IT}_{1}$ than those in season 2 under $\mathrm{IT}_{2}$. A similar result was obtained where coriander biomass and chili pepper growth and fruit characteristics were increased by mild salinity induced by different salts $[35,36]$.

The authors reported that plants irrigated with freshwater with $\mathrm{EC}<4.0 \mathrm{dS} . \mathrm{m}^{-1}$ had the highest fruit yield of $1.52 \mathrm{~kg}$ while the lowest yield of $0.667 \mathrm{~kg}$ was found under higher salinity with EC $10 \mathrm{dS} . \mathrm{m}^{-1}$. However, the growing salinity of irrigation water declined the safflower yield and reduced the saline water application $\left(\mathrm{EC}_{\mathrm{iw}} 3.4 \mathrm{dS} \cdot \mathrm{m}^{-1}\right)$. Nevertheless, this can be improved, during germination, by adopting an effective strategy and efficient saline irrigation [37]. Increased level of salinity decreased $50 \%$ yield of the crop, and it has been reported while investigating the response of Capsicum annuum L. to saline irrigation water in a greenhouse [38].

Compared to $\mathrm{IT}_{2}$, the WUE was high under $\mathrm{IT}_{1}$ as fresh quality irrigation water increases crop yield and water use efficiency. The results are in line with a recent study [39] which reported that a higher WUE was achieved by using low discharge drip irrigation with a discharge rate of 1.6 L.h $\mathrm{h}^{-1}$ in the first year and $0.6 \mathrm{~L} . \mathrm{h}^{-1}$ in the next year on potatoes in the Arava Desert, Israel.

The overall agronomic data indicated that the bitter gourd plants under $\mathrm{IT}_{1}\left(\mathrm{EC}\right.$ of $\left.0.56 \mathrm{dS} . \mathrm{m}^{-1}\right)$ were somewhat healthier than the plants under $\mathrm{IT}_{2}\left(\mathrm{EC}_{\mathrm{iw}} 2.89 \mathrm{dS} . \mathrm{m}^{-1}\right)$. The outcomes were attributed to the saline quality of groundwater affecting the fruit weight, size, and yield although the change was not significant.

\section{Conclusion}

The bitter gourd yield under $\mathrm{IT}_{1}$ (EC of $0.56 \mathrm{dS} . \mathrm{m}^{-1}$ ) was 45.5 t.ha $^{-1}$ and 22.6 t.ha $^{-1}$ in season 1 and 2, respectively, and was found higher in than $33.4 \mathrm{t}_{\mathrm{ha}} \mathrm{h}^{-1}$ and $14.5 \mathrm{t} \cdot \mathrm{ha}^{-1}$ under $\mathrm{IT}_{2}$ $\left(\mathrm{EC}_{\mathrm{iw}} 2.89 \mathrm{dS} . \mathrm{m}^{-1}\right)$ in season 1 and 2, respectively. Overall, the outcome of the research revealed that when fresh and saline irrigation water were applied to bitter gourd through drip irrigation, the crop yield improved. Moreover, the crop yield and water use efficiency were slightly better for freshwater than for saline water. It is concluded that saline water is a viable option which can be used for bitter gourd by using drip technology in the semiarid region. More research should be conducted on moderate saline vegetables under drip irrigation systems by using different quality groundwater on a sustainable basis so that the obtained results can be promoted among farmers.

\section{Data Availability}

The data used to support the findings of this study are available from the corresponding author on request.

\section{Conflicts of Interest}

The authors declare that there are no conflicts of interest.

\section{Acknowledgments}

The authors would like to acknowledge the Pakistan Agricultural Research Council (PARC) and Monash University 
Malaysia for providing research support. The authors also thank the Pakistan Council for Research in Water Resources (PCRWR) for providing laboratory facility for soil and water analysis.

\section{References}

[1] M. Hatamian, A. R. Nejad, M. Kafi, M. K. Souri, and K. Shahbazi, "Nitrate improves hackberry seedling growth under cadmium application," Heliyon, vol. 6, no. 1, Article ID e03247, 2020.

[2] A. Abdelkhalik, N. Pascual-Seva, I. Nájera, A. Giner, C. Baixauli, and B. Pascual, "Yield response of seedless watermelon to different drip irrigation strategies under Mediterranean conditions," Agricultural Water Management, vol. 212, pp. 99-110, 2019.

[3] A. Y. Hoekstra, M. M. Mekonnen, A. K. Chapagain, R. E. Mathews, and B. D. Richter, "Global monthly water scarcity: blue water footprints versus blue water availability," PLoS One, vol. 7, no. 2, Article ID e32688, 2012.

[4] J. Aparicio, A. J. Tenza-Abril, M. Borg, J. Galea, and L. Candela, "Agricultural irrigation of vine crops from desalinated and brackish groundwater under an economic perspective. A case study in Siggiewi, Malta," The Science of the Total Environment, vol. 650, pp. 734-740, 2019.

[5] P. Kumar, A. Sarangi, D. K. Singh, S. S. Parihar, and R. N. Sahoo, "Simulation of salt dynamics in the root zone and yield of wheat crop under irrigated saline regimes using SWAP model," Agricultural Water Management, vol. 148, pp. 72-83, 2015.

[6] U. Water, Managing Water under Uncertainty and Risk, the United Nations World Water Development Report 4, UN Water Reports, World Water Assessment Programme, UNESCO, Paris, France, 2012.

[7] M. Abedinpour, A. Sarangi, T. B. S. Rajput, M. Singh, H. Pathak, and T. Ahmad, "Performance evaluation of AquaCrop model for maize crop in a semi-arid environment," Agricultural Water Management, vol. 110, pp. 55-66, 2012.

[8] J. W. Evans, "The future is now: scenarios to 2025 and beyond," Too Global To Fail, vol. 91, p. 67, 2014.

[9] G. Siamak and S. Srikantaswamy, "Assessment of seasonal variation and drinking water quality in Mysore city," Asian Journal of Environmental Science, vol. 3, pp. 104-110, 2008.

[10] R. Jodder, M. A. Haque, T. Kumar, M. Jahiruddin, M. Z. Rahman, and D. Clarke, "Climate change effects and adaptation measures for crop production in South-West coast of Bangladesh," Research in Agriculture Livestock and Fisheries, vol. 3, no. 3, pp. 369-378, 2016.

[11] M. Ahmadi and M. K. Souri, "Growth and mineral content of coriander (Coriandrum sativum L.) plants under mild salinity with different salts," Acta Physiologiae Plantarum, vol. 40, no. 11, pp. 1-8, 2018.

[12] R. Ahmadi, B. Souri, and M. Ebrahimi, "Evaluation of wheat straw to insulate fired clay hollow bricks as a construction material," Journal of Cleaner Production, vol. 254, Article ID 120043, 2020.

[13] S. Yadav, M. Irfan, A. Ahmad, and S. Hayat, "Causes of salinity and plant manifestations to salt stress: a review," Journal of Environmental Biology, vol. 32, no. 5, pp. 667-85, 2011.

[14] J.-P. Venot, From Obscurity to Prominence: How Drip Irrigation Conquered the World Drip Irrigation for Agriculture, pp. 16-37, Routledge, England, UK, 2017.

[15] K. Laib, T. Hartani, S. Bouarfa, M. Kuper, and J. C. Mailhol, "Connecting drip irrigation performance to farmers' practices: the case of greenhouse horticulture in the Algerian Sahara," Irrigation and Drainage, vol. 67, no. 3, pp. 392-403, 2018.

[16] M. Asif, M. M. Akram, R. M. Asif, and M. A. Rafique, "Impact of drip and furrow irrigation methods on yield, water productivity and fertilizer use efficiency of sweet pepper (Capsicum annuum L.) grown under plastic tunnel," Science Letter, vol. 4, no. 2, pp. 118-123, 2016 b.

[17] M. R. Goyal, Research Advances in Sustainable Micro Irrigation, p. 410, Apple Academic Press Inc, Oakville, ON, Canada, 2015.

[18] M. K. Souri and M. Hatamian, "Aminochelates in plant nutrition: a review," Journal of Plant Nutrition, vol. 42, no. 1, pp. 67-78, 2019.

[19] M. Naiji and M. K. Souri, "Nutritional value and mineral concentrations of sweet basil under organic compared to chemical fertilization," Journal of Hortorum Cultus, vol. 17, no. 2, Article ID 167175, 2018.

[20] W. Morgan and D. Midmore, Bitter Melon in Australia, RIRDC Publication, Kingston ACT, Australia, 2002.

[21] M. J. Atif, G. Jellani, H. Ullah, T. N. Khan, and N. Saleem, "Seedling age impact on growth and yield of bitter gourd," Science, Technology and Development, vol. 35, no. 2, pp. 94-97, 2016.

[22] F. Van Steenbergen, M. Basharat, and B. Lashari, "Key challenges and opportunities for conjunctive management of surface and groundwater in mega-irrigation systems: lower indus, Pakistan," Resources, vol. 4, no. 4, pp. 831-856, 2015.

[23] PMD, "Climate data processing centre (CDPC)," 2017, Retrieved from http://www.pmd.gov.pk/cdpc/extrems/ KARACHI.htm\%20July\%202017.

[24] J. E. Reeb, M. R. Milota, W. D. K. Association, and W. D. K. Association, Moisture Content by the Oven-Dry Method for Industrial Testing, Oregon State University, Corvallis, OR, 1999.

[25] L. Richards, Diagnosis and Improvement of Saline and Alkali Soils, Agriculture, 160, Handbook, 60, United States Salinity Laboratory, USDA, Washington, DC, 1954.

[26] D. Karmeli and J. Keller, Trickle Irrigation Design, Rain Bird Sprinkler Manufacturing Corporation Glendora, CA, 1975.

[27] M. C. Palada and L. C. Chang, "Suggested cultural practices for jute mallow," International Cooperator Guide, vol. 2, no. 14, pp. 1-4, 2003.

[28] A. Yazar, S. M. Sezen, and B. i. Gencel, "Drip irrigation of corn in the southeast anatolia project (GAP) area in Turkey," Irrigation and Drainage, vol. 51, no. 4, pp. 293-300, 2002.

[29] D. K. Majumdar, Irrigation Water Management: Principles and Practice, PHI Learning Pvt. Ltd, New Dehli, 2001.

[30] M. Farhadi Machekposhti, A. Shahnazari, M. Ahmadi, G. Aghajani, and H. Ritzema, "Effect of irrigation with sea water on soil salinity and yield of oleic sunflower," Agricultural Water Management, vol. 188, pp. 69-78, 2017.

[31] N. Ahmed, N. Mahmud, M. Zaman, Z. Ferdous, and S. Halder, "Effect of different salinity level on tomato (Lycopersicon esculentum) production under climate change condition in Bangladesh," Annual Research \& Review in Biology, vol. 13, no. 3, pp. 1-9, 2017.

[32] M. A. Khan, R. Ansari, H. Ali, B. Gul, and B. L. Nielsen, "Panicum turgidum, a potentially sustainable cattle feed alternative to maize for saline areas," Agriculture, Ecosystems \& Environment, vol. 129, no. 4, pp. 542-546, 2009. 
[33] R. Munns and M. Tester, "Mechanisms of salinity tolerance," Annual Review of Plant Biology, vol. 59, no. 1, pp. 651-681, 2008.

[34] M. Kumar, R. Kumar, T. B. S. Rajput, and N. Patel, "Efficient design of drip irrigation system using water and fertilizer application uniformity at different operating pressures in a semi-arid region of India," Irrigation and Drainage, vol. 66, no. 3, pp. 316-326, 2017.

[35] M. Ahmadi and M. K. Souri, "Growth and mineral elements of coriander (Corianderum sativum L.) plants under mild salinity with different salts," Acta Physiologiae Plantarum, vol. 40, pp. 94-99, 2018.

[36] M. Ahmadi and M. K. Souri, "Growth characteristics and fruit quality of chili pepper under higher electrical conductivity of nutrient solution induced by various salts," AGRIVITA, Journal of Agricultural Science, vol. 42, no. 1, pp. 143-152, 2020.

[37] M. Feizi, M. A. Hajabbasi, and B. Mostafazadeh-Fard, "Saline irrigation water management strategies for better yield of safflower (Carthamus tinctorius L.) in an arid region," Australian Journal of Crop Science, vol. 4, pp. 408-414, 2010.

[38] P. Rameshwaran, A. Tepe, A. Yazar, and R. Ragab, "Effects of drip-irrigation regimes with saline water on pepper productivity and soil salinity under greenhouse conditions," Scientia Horticulturae, vol. 199, pp. 114-123, 2016.

[39] P. Trifonov, N. Lazarovitch, and G. Arye, "Increasing water productivity in arid regions using low-discharge drip irrigation: a case study on potato growth," Irrigation Science, vol. 35, pp. 1-9, 2017. 